\title{
PERENCANAAN MODEL DAN STRATEGI PENGELOLAAN SENTRA KELAUTAN DAN PERIKANAN TERPADU (SKPT) BIAK DI KABUPATEN BIAK NUMFOR, PAPUA
}

\section{Model and Strategy Planning on Integrated Management of Biak Marine and Fisheries Center (SKPT) in Biak Numfor District, Papua}

\author{
*Umari Hasan', Harianto' dan Catur Sarwanto \\ ${ }^{1}$ Sekolah Bisnis IPB University \\ Gd. SB-IPB Kampus IPB Gunung Gede, JI. Raya Pajajaran, Kecamatan Bogor Tengah, \\ Kota Bogor, Jawa Barat 16128, Indonesia \\ ${ }^{2}$ Direktorat Usaha dan Investasi - Kementerian Kelautan dan Perikanan \\ Gedung Mina Bahari III Lantai 14 Jl. Medan Merdeka Timur No.16 Jakarta Pusat, Indonesia \\ Diterima tanggal: 9 Mei 2019 Diterima setelah perbaikan: 29 Agustus 2019 \\ Disetujui terbit: 9 Desemeber 2019
}

\begin{abstract}
ABSTRAK
Sentra Kelautan dan Perikanan Terpadu (SKPT) adalah pusat bisnis kelautan dan perikanan terpadu dari hulu ke hilir berbasis kawasan, yang telah dikembangkan oleh Kementerian Kelautan dan Perikanan sejak tahun 2016 melalui berbagai kegiatan seperti pembangunan fasilitas usaha, fasilitas pendukung, penyaluran bantuan usaha, dan pelatihan tenaga kerja perikanan. Kawasan SKPT Biak belum beroperasi secara maksimal karena beberapa hal, antara lain belum memiliki model dan strategi pengelolaan kawasan. Penelitian ini memiliki tiga tujuan utama, yaitu: 1) menyusun model pengelolaan SKPT Biak; 2) mengidentifikasi faktor-faktor internal dan eksternalyang mempengaruhi pengelolaan SKPT Biak; 3) merumuskan alternatif dan prioritas strategi pengelolaan. Metode yang digunakan dalam penelitian ini adalah metode deskriptif dengan menggunakan Business Model Canvas (BMC) yang disesuaikan untuk organisasi non-profit, serta analisis strengths, weaknesses, opportunities, threats (SWOT) yang diintegrasikan dengan Analitycal Hierarchy Process (AHP). Hasil analisis pada penelitian ini adalah model pengelolaan SKPT Biak, yang memilikitiga segmen yang dinilai relatif lebih penting dan sangat mempengaruhi kesuksesan segmen lainnya yaitu: Proporsi Nilai, Aktifitas Kunci, dan Arus Pendapatan. Prioritas strategi yang dirumuskan, yaitu: (1) Mengoptimalkan semua sumber daya produksi untuk menciptakan nilai yang dapat meningkatkan loyalitas pelanggan dan mitra, serta untuk menarik pelanggan dan investor baru; (2) Melakukan promosi peluang investasi dan kerja sama, serta mengusulkan alokasi bantuan dalam rangka mengoptimalkan seluruh aktifitas dalam kawasan SKPT Biak; (3) Penyusunan peraturan penerapan retribusi, sistem pembayaran, pengelolaan, dan sanksi dengan melibatkan Pemeritah, asosiasi usaha, dan instansi terkait lainnya; serta (4) Menyusun perencanaan seluruh kegiatan dan anggaran dalam rangka optimalisasi pengelolaan kawasan SKPT Biak, untuk diusulkan kepada Kementerian Kelautan dan Perikanan (KKP), kementerian terkait, serta Badan Usaha Milik Negara/Badan Usaha Milik Swasta (BUMN/BUMS) penyalur Corporate Social Responsibility/Program Kemitraan dan Bina Lingkungan (CSR/PKBL).
\end{abstract}

Kata Kunci: bisnis perikanan; SKPT Biak; model pengelolaan; strategi; kawasan perikanan; pengelolaan terpadu

\section{ABSTRACT}

Integrated Marine and Fisheries Center (SKPT) is an integrated marine and fisheries business center from the upstream to downstream based on area, which has been developed by the Ministry of Marine Affairs and Fisheries since 2016 through various activities, such as the construction of business facilities, supporting facilities, business support distribution, and training for fisheries labors. The SKPT Biak area has not yet operated optimally due to several factors, including the lack of area management model and strategy. This research has three main objectives namely : 1) develop a SKPT Biak management model; 2) identify internal and external factors that affect the management of SKPT Biak; 3) formulate alternative and priority management strategies. The method used in this research is descriptive method using Business Model Canvas (BMC) which is adjusted for non-profit organizations, as well as strengths, weaknesses, opportunities, threats (SWOT) analysis which is integrated with the Analitycal Hierarchy Process (AHP). The results of the analysis inthis study is management model of SKPT Biak, that the segments that are considered relatively more important and greatly affect the success of other segments, that is: Proportion of Values, Key Activities, and Revenues. Formulated 
priority strategies are: (1) Optimizing all production resources to create value that can increase customer and partner loyalty, and to attract new customers and investors; (2) Promoting investment opportunities and cooperation, and proposing the allocation of assistance in order to optimize all activities in the SKPT Biak area; (3) Formulation of regulations on user fees, payment systems, management, and sanctions involving the Government, business associations, and other relevant agencies; and (4) Arranging the planning of all activities and budgets in the context of optimizing the management of the Biak SKPT area, to be proposed to the KKP, relevant ministries, as well as BUMN/BUMS channeling CSR /PKBL.

\section{Keywords: fisheries business; SKPT Biak; management model; strategy; fisheries area; integrated management}

\section{PENDAHULUAN}

Kabupaten Biak Numfor terletak di Wilayah Pengelolaan Perikanan (WPP) 717, yang memiliki potensi lestari (Maximum Sustainable Yield) mencapai 603.688 ton/tahun, dimana tingkat pemanfaatannya hanya sebesar 336.618 ton/ tahun atau $55,76 \%$ dari potensi lestari (KKP, 2016). Pada tahun 2016 Kementerian Kelautan dan Perikanan melakukan inisiasi dan fasilitasi pembangunan Sentra Kelautan dan Perikanan Terpadu (SKPT), yang dipusatkan di Pangkalan Pendaratan Ikan (PPI) Fandoi, Distrik Biak Kota. SKPT merupakan konsep pembangunan kelautan dan perikanan berbasis wilayah dengan pendekatan dan sistem manajemen kawasan dengan prinsip integrasi, efisiensi, kualitas dan akselerasi tinggi. Pengembangan industri perikanan melalui SKPT ini sesuai dengan penelitian (Johansen et al., 2019) yang menyebutkan bahwa kegiatan ekonomi kelautan dunia akan tumbuh pesat dan diperkirakan mampu menyediakan jutaan lapangan pekerjaan dan mengggandakan kontribusinya terhadap penciptaan nilai global.

Berbagai kegiatan dan fasilitas yang telah dibangun di PPI Fandoi sebagai kawasan inti SKPT, antara lain : gudang beku terintegrasi dengan unit pengolahan ikan, pasar ikan, fasilitas pendaratan ikan, dermaga, Solar Packed Dealer Nelayan (SPDN), dan fasilitas umum (jalan, intalasi listrik, instalasi air bersih, IPAL kawasan, drainase, dan sebagainya). Untuk menjaga mutu hasil tangkapan, Pemerintah juga memberikan bantuan berupa : chest freezer, coolbox, ice flake machine, dan kendaraan roda 6 berpendingin sebagai sarana untuk mewujudkan berjalannya sistem rantai dingin yang baik. Infrastruktur pendukung lainnya yaitu tersedianya bandara Frans Kaisepo, pelabuhan umum, surplus kapasitas listrik kabupaten sekitar 2,5 MW, dan ketersediaan air bersih melalui PDAM.

Saatinikawasan SKPTBiak belum beroperasi secara menyeluruh karena beberapa kendala, antara lain: proses pembangunan belum selesai semuanya, belum dilakukan penetapan lembaga pengelola kawasan SKPT, belum memiliki model dan strategi pengelolaan kawasan, operator yang kurang profesional dan kekurangan modal, mesin dan peralatan rusak, dan beberapa fasilitas yang tidak berfungsi dengan optimal. Belum adanya model dan strategi pengelolaan kawasan SKPT Biak adalah kendala utama yang sangat penting dan mendesak untuk diselesaikan karena akan sangat mempengaruhi fungsi Unit Pengelola SKPT Biak dalam mencapai tujuan pembangunan SKPT Biak. Oleh karena itu, penelitian ini dilakukan untuk menyusun prototipe model pengelolaan SKPT, mengidentifikasi faktor-faktor yang mempengaruhi, dan menentukan alternatif strategi yang dapat dilakukan untuk mengelola kawasan SKPT Biak secara optimal sehingga tujuan pembangunan SKPT Biak dapat segera terwujud. Jadi ruang lingkup penelitian ini hanya dibatasi untuk menjawab permasalahan belum adanya model dan strategi pengelolaan kawasan SKPT Biak, sedangkan permasalahan yang lain diabaikan atau tidak dibahas secara detail. Penelitian ini juga dilakukan untuk melengkapi Masterplan dan Bisnis Plan Pembangunan Sentra Kelautan dan Perikanan Terpadu (SKPT) Kabupaten Biak Numforyang belum memuat terkait model dan strategi pengelolaan SKPT Biak, serta untuk menindaklanjuti penelitian dari Koeshendrajana, Zamroni, Asnawi, Wijaya, \& Rosyidah (2018) yang menyebutkan bahwa tingkat keberhasilan SKPT Biak jika dikelola oleh pemerintah pusat atau unit pelaksanan teknis dari Kementerian Kelautan dan Perikanan (UPT KKP) adalah lebih tinggi dibandingkan dengan dikelola oleh Pemerintah Provinsi Papua atau Pemerintah Kabupaten Biak Numfor.

Penelitian ini dilakukan di kawasan SKPT Biak, yang terletak di Kelurahan Fandoi, Distrik Biak Kota, Kabupaten Biak Numfor, Papua. Penelitian ini dilakukan pada bulan November 2018 sampai dengan Februari 2019. Metode yang digunakan dalam penelitian ini adalah metode deskriptif dengan menggunakan Business Model Canvas 
(BMC) dan analisis SWOT yang diintegrasikan dengan Analitycal Hierarchy Process (Osuna \& Aranda, 2007), seperti yang dilakukan oleh Destiani (2015) serta Rohy, Kadir \& Alam (2015). Penyusunan model pengelolaan SKPT Biak dalam penelitian ini dilakukan dengan melakukan penyesuaian BMC dengan menambahkan dua segmen, yaitu: segmen Missions dan segmen Impact \& Measurement. Hal tersebut dilakukan sesuai dengan penelitian Qastharin (2016), dimana penambahan segmen tersebut dilakukan untuk menyusun model bisnis pada organisasi non-profit. Analisa Streght Weakness Opportunity and Threats (SWOT) dilakukan untuk mengidentifikasi faktorfaktor yang mempengaruhi pengelolaan SKPT Biak dan menyusun alternatif strategi. Analitycal Hierarchy Process (AHP) digunakan untuk memilih strategi prioritas dari alternatif strategi yang tersusun. Responden yang terlibat dalam penelitian ini berjumlah 10 orang, yang ditentukan secara sengaja berdasarkan pertimbangan pengetahuan, kemampuan, dan pengalaman responden dalam bidang yang diteliti, serta keterlibatannya dalam proses pelaksanaan program SKPT Biak dan memiliki andil dalam penentuan kebijakan pengelolaan SKPT Biak, yaitu dari KKP, Dinas Kelautan dan Perikanan Provinsi Papua, serta Dinas Perikanan Kabupaten Biak Numfor.

\section{KARATERISTIK SEKTOR KELAUTAN DAN PERIKANAN}

Kabupaten Biak Numfor terdiri dari pulaupulau, yang secara geografis terletak pada posisi antara $134^{\circ} 47^{\prime}-136^{\circ} 45^{\prime}$ Bujur Timur dan $0^{\circ}$ $55^{\prime}-1^{\circ} 27^{\prime}$ Lintang Selatan. Luas daratan sebesar $3.130 \mathrm{Km}^{2}$ dan luas lautan $18.442 \mathrm{Km}^{2}$, selebihnya merupakan gugusan pulau-pulau kecil dengan luas keseluruhan $483 \mathrm{Km}^{2}$ (Kementerian Kelautan dan Perikanan, 2016). Berdasarkan kontribusi masingmasing sektor terhadap total PDRB Kabupaten Biak Numfor masih sangat dominan dari sektor pertanian, dimana sub sektor perikanan sangat mendominasi yaitu sekitar 20\%. Kabupaten Biak Numfor memiliki jumlah Rumah Tangga Perikanan (RTP) mencapai 6.019, yang mampu menghasilkan produksi perikanan mencapai 80.175 ton/tahun. Armada penangkapan ikan yang digunakan oleh nelayan di Kabupaten Biak Numfor berjumlah 6.227 unit, yang terdiri atas perahu tanpa motor (PTM), perahu motor tempel (PMT) dan kapal motor (KM). Jumlah alat penangkapan ikan mencapai 15.807 unit, yang terdiri dari : pancing, jaring insang, dan alat penangkapan lainnya (Dinas Perikanan Kab. Biak Numfor, 2018). Komoditas unggulan untuk perikanan tangkap yaitu: pelagis besar, pelagis kecil, dan demersal/dasar, dengan perkembangan produksi perikanan tahun 2014 - 2018 tertera pada Gambar 1.

Pengembangan usaha budidaya ikan juga sangat berpotensi untuk dilakukan karena Biak Numfor memiliki luas lokasi budidaya mencapai 2.381.408 Ha. Komoditas perikanan budidaya yang dapat dikembangkan yaitu: ikan kerapu, rumput laut, kerang/teripang, dan tiram mutiara. Usaha pengolahan hasil kelautan dan perikanan belum berkembang pesat di Biak Numfor dan sangat berpotensi untuk dikembangkan lebih lanjut. Hal tersebut sesuai dengan penelitian Kurniasari, Rosidah, \& Erlina (2019) yang menyebutkan bahwa pengembangan usaha pengolahan dapat menjadi solusi terhadap permasalahan perikanan tangkap, seperti: kelebihan suplai ikan pada musim tertentu, keterbatasan fasilitas penampung ikan, dan tingginya biaya transportasi ikan segar.

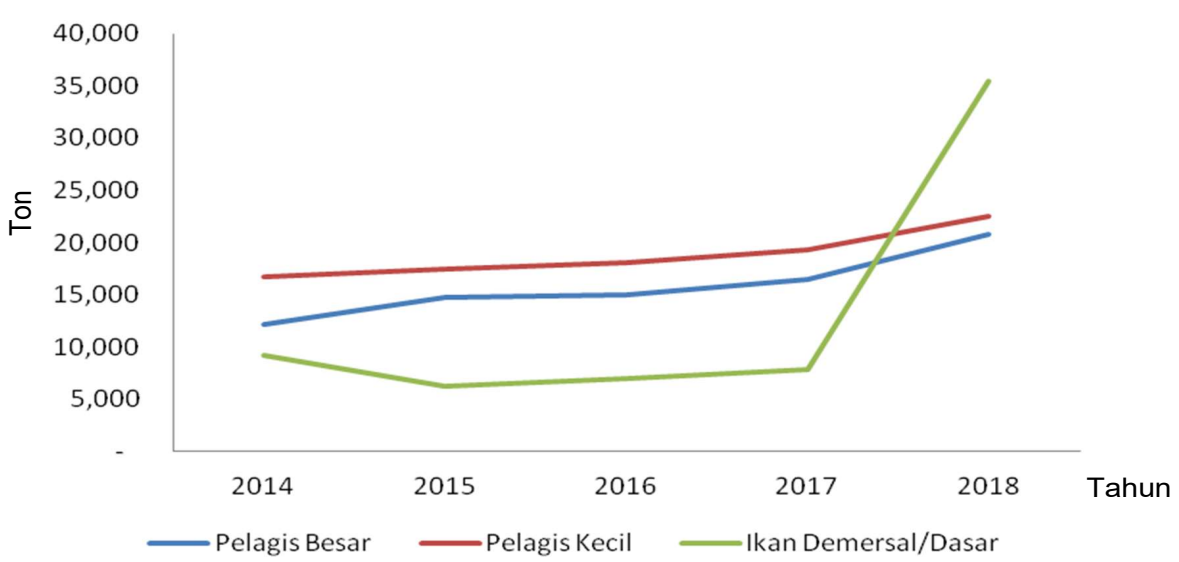

Gambar 1. Pertumbuhan Produksi Komoditas Perikanan Unggulan di Kabupaten Biak Numfor Tahun 2014-2018. Figure 1. Production Growth of Mainstay Fisheries Commodity in Biak Numfor District for 2014 - 2018. 
Saat ini hanya berjumlah sekitar 30 kelompok dengan jenis produknya yaitu: ikan cakalang asap, abon ikan, ikan asin, bakso tuna, stik rumput laut, dan loin tuna. Adapun usaha pemasaran ikan cukup berkembang dengan didukung fasilitas pemasaran ikan yang cukup memadai, dengan fasilitas utama yaitu: Pasar Ikan Fandoi, Pasar Tradisional Karmel Bosnik, dan Pasar Induk.

Pencanangan Sentra Kelautan dan Perikanan Terpadu (SKPT) Biak telah dilakukan Menteri Kelautan dan Perikanan sejak tahun 2016 melalui Surat Keputusan Menteri Nomor 51/KEPMEN-KP/2016 tentang Penetapan Lokasi Pembangunan Sentra Kelautan dan Perikanan Terpadu di Pulau-Pulau Kecil dan Kawasan Perbatasan, yang mempunyai tujuan, yaitu: Membangun sarana prasarana kelautan dan perikanan; Mengembangkan kelembagaan berbasis masyarakat; Mengintegrasikan proses bisnis perikanan; serta Optimalisasi pemanfaatan sumber daya kelautan dan perikanan. Pada tahap awal, Pemerintah melakukan berbagai kegiatan, seperti: pembangunan fasilitas usaha (gudang beku terintegrasi, PPI, pasar ikan, dermaga, dan lain-lain), fasilitas pendukung (instalasi air bersih, instalasi listrik, jalan kawasan, IPAL, dan lain-lain), penyaluran bantuan usaha (kapal, alat tangkap, chest freezer, coldbox, dan lain-lain), dan pelatihan tenaga kerja perikanan (pelatihan penggunaan alat tangkap, pembesaran ikan air tawar, perawatan mesin kapal, dan lain-lain). Penampakan kawasan inti SKPT Biak seperti pada Gambar 2.

Aktifitas usaha perikanan dalam kawasan inti SKPT Biak yaitu PPI Fandoi akan berlangsung secara terintegrasi dari hulu ke hilir. Kegiatan bisnis perikanan dimulai dari penyediaan kebutuhan logistik nelayan (seperti: alat tangkap, es balok, BBM, serta persediaan makanan), kegiatan tambat labuh, pendaratan ikan, pelelangan/pemasaran, penanganan dan pengolahan (meliputi: pembekuan dan filleting), izin dan karantina, hingga distribusi ikan. Unit Pengelola SKPT Biak merupakan Unit Pelaksana Teknis Kementerian Kelautan dan Perikanan dimana penetapan status lembaga tersebut masih dibahas dengan Kementerian Pendayagunaan Aparatur Negara dan Reformasi Birokrasi. Tugas utama Unit Pengelola SKPT Biak adalah memberikan pelayanan kepada unit usaha/ lembaga dan pelaku usaha perikanan dalam pengembangan bisnisnya, sedangkan tugas kedua yaitu menjalankan fungsi bisnis dalam mengelola fasilitas-fasilitas usaha milik Pemerintah, meliputi: dermaga, PPI, gudang beku terintegrasi, gudang, pabrik es, dan pasar ikan.

\section{MODEL PENGELOLAAN SKPT BIAK}

Penyusunan model pengelolaan SKPT Biak dilakukan untuk mengetahui elemen-elemen model pengelolaan SKPT Biak sesuai dengan Business Model Canvas (BMC). Menurut Osterwalder dan Pigneur (2015), menyusun BMC dilakukan dengan membuat suatu kerangka Business Model yang berbentuk kanvas dan terdiri dari 9 kotak yang saling berkaitan. Kotak-kotak ini berisikan elemen-elemen penting yang menggambarkan bagaimana organisasi menciptakan manfaat bagi dan mendapat manfaat dari para pelanggannya. Hasil penyusunan model pengelolaan SKPT Biak terinci pada Tabel 1.

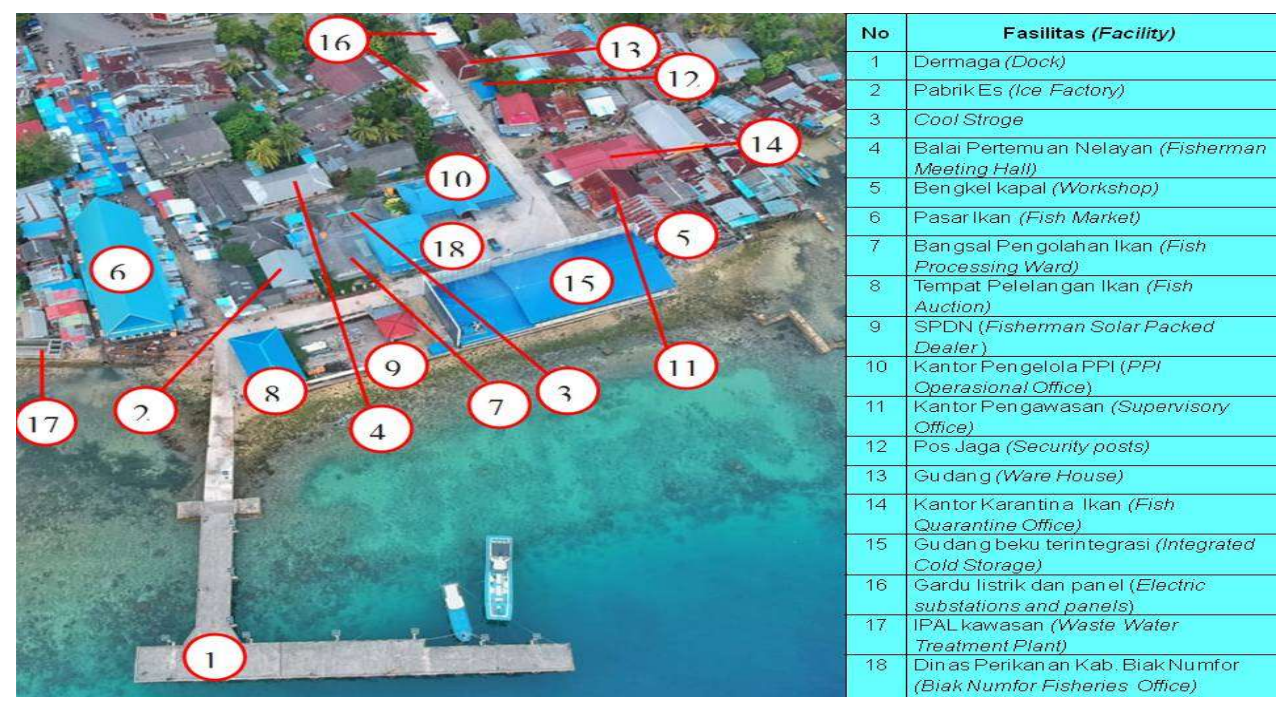

Gambar 2. Kawasan Inti SKPT Biak.

Figure 2. Core Area of SKPT Biak. 


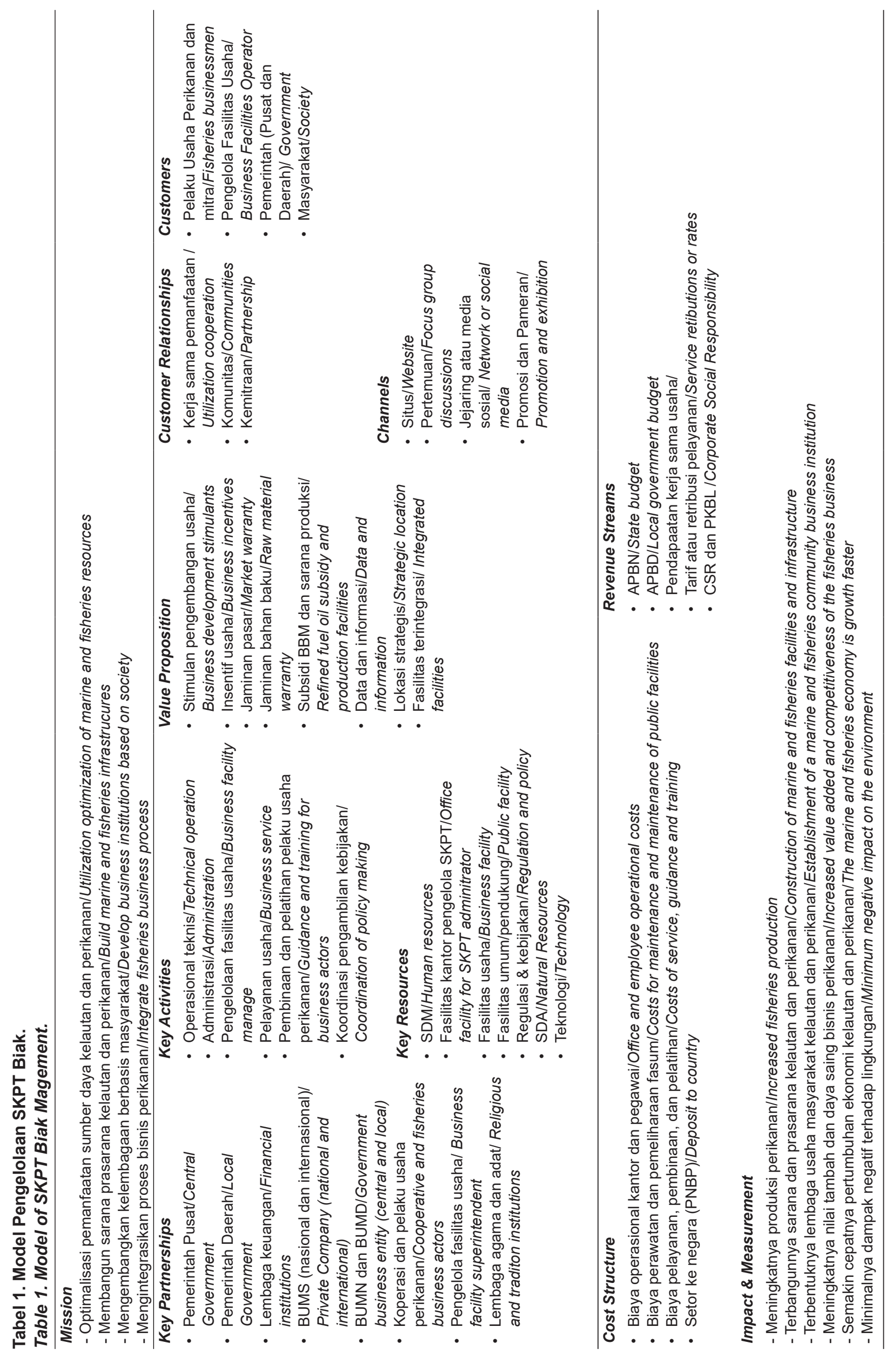


Unit pengelola SKPT Biak merupakan lembaga non profit yang ditunjuk oleh Menteri Kelautan dan Perikanan untuk mengelola kawasan SKPT sehingga pada prototype model pengelolaan SKPT Biak disusun dalam bentuk BMC yang dimodifikasi dengan dua segmen tambahan, yaitu segmen Mission dan segmen Impact \& Measurement. Dalam penelitian ini segmen Mission adalah tujuan dibangunnya SKPT Biak, yaitu: Membangun sarana prasarana kelautan dan perikanan; Mengembangkan kelembagaan berbasis masyarakat; Mengintegrasikan proses bisnis perikanan; serta Optimalisasi pemanfaatan sumber daya kelautan dan perikanan. Segmen dampak dan pengukuran (Impact \& Measurement) adalah segmen yang perlu diidentifikasi dan dimasukkan dalam model pengelolaan SKPT Biak untuk mengukur tingkat keberhasilan unit pengelola SKPT Biak dalam menjalankan fungsi pelayanannya (non-profit oriented). Pengembangan SKPT Biak dinilai berhasil oleh Pemerintah jika mampu memberikan dampak positif terhadap lingkungan dan masyarakat dalam rangka mewujudkan tujuan pembangunan SKPT Biak. Secara umum, dampak positif dapat dirasakan dalam tiga aspek, yaitu: dampak ekonomi, dampak sosial, dan dampak lingkungan. Hal tersebut sesuai dengan penelitian Adam \& Surya (2013), yang menyebutkan bahwa faktor-faktor dominan dalam pengembangan sektor perikanan secara berkelanjutan harus dinilai dari aspek lingkungan, aspek sosial, dan aspek ekonomi. Evaluasi terhadap aspek sosial dan ekonomi ini juga sangat penting untuk mengetahui kinerja pengelolaan sektor perikanan (Smith, Karasik, Stavrinaky, Uchida, \& Burden, 2019).

\section{Faktor Internal dan Eksternal, serta Alternatif Strategi}

Dalam penelitian ini penyusunan alternatif strategi dilakukan pada tiga segmen yang dipilih berdasarkan masukan dari responden. Pemilihan terhadap tiga segmen tersebut dilakukan karena ketiga segmen tersebut dinilai sangat strategis dan mampu menentukan keberhasilan strategi dari enam segmen lainnya sehingga pencapaian tujuan pembangunan SKPT Biak dapat tercapai lebih mudah dan cepat. Tiga segmen dimaksud yaitu: Proporsi Nilai, Aktifitas Kunci, dan Arus Pendapatan. Identifikasi faktor internal dan eksternal dilakukan terhadap ketiga segmen tersebut dengan tujuan untuk mengetahui faktor-faktor yang mempengaruhi pelaksanaan kegiatan-kegiatan dalam masing-masing segmen.
Faktor internal dan eksternal masing-masing segmen disusun dalam matrik SWOT kemudian dilakukan analisis untuk membentuk altenatif Strategi S-O, Strategi W-O, Strategi S-T, dan Strategi W-T. Hal tersebut sesuai dengan pendapat Kotler \& Keller (2009) yang menyebutkan bahwa analisis SWOT penting untuk dilakukan merumuskan manajemen strategi yang akan dijalankan perusahaan agar siap bersaing. Salah satu yang menjadi pertimbangan dalam menentukan strategi yaitu ancaman konflik yang dapat mengganggu kelancaran operasionalisasi SKPT Biak. Konflik akan selalu ada jika ada perbedaan kepentingan ekonomi, agama, politik, etnis, dan budaya, sehingga harus dapat dicegah atau dikelola dengan pendekatan yang humanis namun tegas (Palilu, 2019).

\section{A. Segmen Proporsi Nilai}

Nilai (value) adalah produk yang harus dihasilkan pengelola SKPT Biak dalam rangka memenuhi kebutuhan dan permintaan pelanggan. Proporsi nilai yang baik diharapkan dapat meningkatkan jumlah pelanggan dan meningkatkan loyalitas mereka. Nilai yang diciptakan oleh SKPT Biak, yaitu: stimulan pengembangan usaha, insentif usaha, jaminan pasar, jaminan bahan baku, subsidi BBM dan sarana produksi, data dan informasi, lokasi strategis, serta fasilitas yang terintegrasi. Oleh karena itu, perlu disusun strategi untuk mengoptimalkan nilai yang diciptakan oleh unit pengelola SKPT Biak, baik itu fungsi pelayanan maupun fungsi bisnis. Adapun faktor-faktor internal dan eksternal yang mempengaruhi segmen Proporsi Nilai dan hasil penyusunan alternatif strategi untuk segmen ini dapat dilihat pada Tabel 2.

\section{B. Segmen Aktifitas Kunci}

Aktifitas kunci adalah salah satu segmen yang menjadi prioritas karena dinilai sangat berhubungan dengan segmen lain dalam kegiatan pengelolaan kawasan SKPT Biak, yaitu dengan memanfaatkan sumber daya yang ada dan didukung oleh mitrra utama untuk menyalurkan nilai SKPT Biak kepada pelanggan. Aktifitas kunci yang diterapkan secara efektif dan efisien dapat mengoptimalkan biaya/anggaran operasional untuk memperoleh pendapatan yang wajar dan menghasilkan dampak positif kepada masyarakat (terutama pelaku usaha dalam kawasan SKPT Biak), baik dampak ekonomi, sosial, maupun lingkungan. Adapun aktifitas kunci dimaksud, yaitu: operasional teknis, administrasi, pengelolaan 
Tabel 2. Hasil Penyusunan Alternatif Strategi Segmen Proporsi Nilai. Table 2. Alternative Strategy Compilation Results for Value Proportion Segments.

\begin{tabular}{|c|c|c|}
\hline & Kekuatan/Strenghts (S) & Kelemahan/Weakness (W) \\
\hline External & $\begin{array}{l}\text { 1. Kemudahan memperoleh data } \\
\text { internal dalam kawasan SKPT Biak/ } \\
\text { Easy to get internal data in the Biak } \\
\text { SKPT area } \\
\text { 2. Memiliki hubungan yang baik } \\
\text { dengan Pemerintah Daerah dan } \\
\text { stakeholders/ Good relationships with } \\
\text { local governments and stakeholders } \\
\text { 3. Akses informasi pasar ikan nasional/ } \\
\text { Have accessto national fish market } \\
\text { information } \\
\text { 4. Mudah mendapatkan rekomenda si } \\
\text { terkait pengembangan usaha/Easily } \\
\text { to get recommendations of business } \\
\text { development }\end{array}$ & $\begin{array}{l}\text { 1. Sistem data dan informasi yang } \\
\text { dikelola unit pengelola masih belum } \\
\text { matang/Management of data and } \\
\text { information system is weak } \\
\text { 2. Tidak semua pelanggan dapat } \\
\text { memperoleh insentif /Not all of } \\
\text { customers can get incentives } \\
\text { 3. Stimulan kemudahan berusaha } \\
\text { terbatas/Business stimulant is } \\
\text { limited } \\
\text { 4. Keterbatasan kemampuan SDM } \\
\text { dalam menciptakan nilai yang } \\
\text { diinginkan pelanggan/Ability } \\
\text { limitations of employee to create } \\
\text { value to customers }\end{array}$ \\
\hline Peluang/Opportunities (O) & Strategy S-O & Strategy $\mathbf{W}-0$ \\
\hline $\begin{array}{l}\text { 1. Mendapatkan prioritas dukungan dari } \\
\text { Pemerintah/Get priority support from the } \\
\text { Government } \\
\text { 2. Belum ada kawasan usaha di Biak } \\
\text { Numfor yang memiliki fasilitas lengkap } \\
\text { seperti SKPT Biak/There is no business } \\
\text { area in Biak Numfor that has complete } \\
\text { facilities such as SKPT Biak }\end{array}$ & $\begin{array}{l}\text { Memaksimalkan fungsi pelayanan } \\
\text { dalam kawasan SKPT Biak dan } \\
\text { optimalisasi SDA dalam rangka } \\
\text { memacu fungsi bisnis yang berdampak } \\
\text { positif kepada masyarakat/ Maximizing } \\
\text { service functions in the SKPT Biak area } \\
\text { and optimizing utilization of natural } \\
\text { resources to spur business functions }\end{array}$ & $\begin{array}{l}\text { Memaksimalkan jaringan informasi } \\
\text { dan sistem data lingkup KKP dan } \\
\text { kementerian/lembaga lintas sektor, } \\
\text { serta membuat program pelatihan } \\
\text { SDM/Maximizing information networks } \\
\text { and data systems in the scope of } \\
\text { MMAF and ministries/Institutions } \\
\text { across sectors, and making HR }\end{array}$ \\
\hline $\begin{array}{l}\text { 3. Dekat dengan bandara, pelabuhan } \\
\text { umum, dan kantor Pemerintahan/Close }\end{array}$ & that have a positive impact to society & training programs \\
\hline $\begin{array}{l}\text { to airports, public ports, and government } \\
\text { offices }\end{array}$ & $(\mathrm{S} 1, \mathrm{~S} 3, \mathrm{~S} 4, \mathrm{O} 1, \mathrm{O} 2, \mathrm{O} 3, \mathrm{O} 4, \mathrm{O} 5, \mathrm{O} 6)$ & (W1, W4, 01,05) \\
\hline $\begin{array}{l}\text { 4. Dekat dengan pusat bisnis dan kawasan } \\
\text { pemukiman/Close to the business center } \\
\text { and residential area }\end{array}$ & & \\
\hline $\begin{array}{l}\text { 5. Peluang kerja sama penyaluran bantuan } \\
\text { dan CSR/PKBL untuk stakeholders/ } \\
\text { Opportunities for cooperation in } \\
\text { channeling aid and CSR for stakeholders }\end{array}$ & & \\
\hline $\begin{array}{l}\text { 6. SDA melimpah/Abundant natural } \\
\text { resources }\end{array}$ & & \\
\hline Ancaman/Threats $(\mathrm{T})$ & Strategy S-T & Strategy $\mathbf{W}-\mathrm{T}$ \\
\hline $\begin{array}{l}\text { 1. Perubahan kebijakan Pemerintah } \\
\text { terkait insentif kemudahan berusaha } \\
\text { dan stimulan/bantuan/Changes in } \\
\text { Government policies about business } \\
\text { incentives and stimulants }\end{array}$ & $\begin{array}{l}\text { Mengoptimalkan semua sumber daya } \\
\text { produksi (terutama SDM dan fasilitas } \\
\text { dalam kawasan) untuk menciptakan } \\
\text { nilai yang dapat meningkatkan loyalitas } \\
\text { pelanggan dan mitra, serta untuk }\end{array}$ & $\begin{array}{l}\text { Koordinasi teknis lingkup KKP dan } \\
\text { antar kementerian/lembaga dalam } \\
\text { rangka alokasi dan penyaluran insentif } \\
\text { dan stimulan usaha bagi pelaku usaha } \\
\text { di kawasan SKPT Biak/Technical }\end{array}$ \\
\hline $\begin{array}{l}\text { 2. Adanya rencana pembangunan } \\
\text { pelabuhan perikanan dengan fungsi } \\
\text { yang mirip dengan fungsi SKPT/Plan } \\
\text { to develop a fishery port with functions } \\
\text { similar to SKPT functions }\end{array}$ & $\begin{array}{l}\text { menarik pelanggan dan investor baru } \\
\text { /Optimizing all production resources } \\
\text { (especially human resources and } \\
\text { area facilities) to create value that can } \\
\text { increase customer and partner loyalty, }\end{array}$ & $\begin{array}{l}\text { coordination of the scope of the MMAF } \\
\text { and between ministries/institutions } \\
\text { in the context of allocating and } \\
\text { channeling incentives and business } \\
\text { stimulants for business actors in the }\end{array}$ \\
\hline 3. Perubahan karateristik SDM lokal / & and to attract new customers and & SKPT Biak area \\
\hline Changes in local HR characteristics & $\begin{array}{l}\text { investors } \\
(\mathrm{S} 1, \mathrm{~S} 2, \mathrm{~S} 3, \mathrm{~S} 4, \mathrm{~T} 2, \mathrm{~T} 3)\end{array}$ & (W2, W3, T1) \\
\hline
\end{tabular}

fasilitas usaha, pelayanan usaha, serta pembinaan dan pelatihan pelaku usaha perikanan. Adapun faktor-faktor internal dan eksternal yang mempengaruhi segmen Aktifitas Kunci dan hasil penyusunan alternatif strategi untuk segmen ini dapat dilihat pada Tabel 3.

\section{Segmen Arus Pendapatan}

Segmen arus pendapatan menggambarkan muara dari seluruh segmen model pengelolaan SKPT Biak, dimana pada segmen ini dapat diukur apakah seluruh aktifitas kunci yang dilakukan dengan sumber daya yang tersedia dan menggunakan struktur biaya yang tersusun, telah berjalan secara efektif sehingga menghasilkan pendapatan yang wajar dan menimbulkan dampak positif terhadap masayarakat. Dalam segmen ini fungsi bisnis diukur dengan jumlah pendapatan wajar yang diterima unit pengelola SKPT Biak, dimana yang dimaksud wajar yaitu pendapatan yang diperoleh berdasarkan peraturan yang berlaku (yaitu tarif, biaya sewa, dan bagi hasil KSP) mengingat unit pengelola SKPT Biak adalah UPT KKP yang bersifat non-profit. 
Tabel 3. Hasil Penyusunan Alternatif Strategi Segmen Aktifitas Kunci. Table 3. Alternative Strategy Compilation Results for Key Activities Segments.

\begin{tabular}{|c|c|c|}
\hline$\searrow$ & $\begin{array}{l}\text { Kekuatan/Strenghts (S) } \\
\text { 1. Proses bisnis perikanan saling } \\
\text { terintegrasi/The fisheries business } \\
\text { process is integrated with each other } \\
\text { 2. Menguasai seluk beluk bisnis } \\
\text { perikanan dalam kawasan/Mastering } \\
\text { fisheries business based area } \\
\text { 3. Fasilitas usaha dan pendukung relatif } \\
\text { lengkap untuk mendukung aktifitas } \\
\text { bisnis dan pelayanan dalam kawasan } \\
\text { SKPT Biak/Business and supporting } \\
\text { facilities are relatively complete } \\
\text { to support business activities and } \\
\text { services within the SKPT Biak area }\end{array}$ & $\begin{array}{l}\text { Kelemahan/Weakness (W) } \\
\text { 1. Belum ada Perda yang } \\
\text { mendukung pelimpahan } \\
\text { wewenang pengelolaan fasilitas } \\
\text { dalam kawasan SKPT Biak/ } \\
\text { There is no Regional Regulation } \\
\text { that supports the delegation of } \\
\text { authority to manage facilities in } \\
\text { the SKPT Biak area } \\
\text { 2. Keterbatasan jumlah SDM yang } \\
\text { kompeten/Limited number of } \\
\text { competent human resources } \\
\text { 3. SOP untuk pelaksanaan } \\
\text { kegiatan utama dalam } \\
\text { kawasan SKPT Biak belum } \\
\text { teruji efektifitasnya/The } \\
\text { effectiveness of the SOP for } \\
\text { the implementation of the main } \\
\text { activities in the SKPT Biak area }\end{array}$ \\
\hline Peluang/Opportunities (0) & Strategy S-O & Strategy W-O \\
\hline $\begin{array}{l}\text { 1. Masuknya investor baru dalam kawasan } \\
\text { SKPT Biak dapat memacu aktivitas bisnis } \\
\text { yang baru / The entry of new investors } \\
\text { in the SKPT Biak area can spur new } \\
\text { business activities } \\
\text { 2. Sumber daya pendukung terbuka lebar, } \\
\text { seperti: bahan baku, listrik, air bersih/ } \\
\text { Supporting resources are wide open, such } \\
\text { as: raw materials, electricity, fresh water } \\
\text { 3. Banyak program pelayanan Pemerintah } \\
\text { yang dapat dilakukan dalam kawasan } \\
\text { SKPT, baik untuk pelanggan maupun } \\
\text { mitranya/ Many Government service } \\
\text { programs can be carried out within the } \\
\text { SKPT area, both for customers and } \\
\text { partners }\end{array}$ & $\begin{array}{l}\text { Melakukan promosi peluang investasi } \\
\text { dan kerja sama, serta mengusulkan } \\
\text { alokasi bantuan lintas sektor dalam } \\
\text { rangka mengoptimalkan seluruh } \\
\text { aktifitas dalam kawasan SKPT Biak/ } \\
\text { Promoting opportunities for investment } \\
\text { and cooperation, and proposing the } \\
\text { allocation of cross-sector assistance } \\
\text { in order to optimize all activities in the } \\
\text { SKPT Biak area } \\
\text { (S1,S2,S3, O1,O2,O3) }\end{array}$ & $\begin{array}{l}\text { Pelatihan SDM secara periodik } \\
\text { dan berjenjang, serata melakukan } \\
\text { penyusunan SOP yang efektif dan } \\
\text { efisien / Periodic and tiered HR } \\
\text { training, while making effective and } \\
\text { efficient SOP arrangements } \\
\text { (W2,W3,O3) }\end{array}$ \\
\hline Ancaman/Threats (T) & Strategy S-T & Strategy W-T \\
\hline $\begin{array}{l}\text { 1. Adanya regulasi Pemerintah yang } \\
\text { membatasi aktifitas dalam kawasan } \\
\text { SKPT / Government regulations that limit } \\
\text { activities within the SKPT area } \\
\text { 2. Pelaku usaha tidak mendukung kegiatan } \\
\text { bisnis perikanan dalam kawasan SKPT } \\
\text { Biak/Business actors do not support } \\
\text { fiheries business activities in the SKPT } \\
\text { Biak area } \\
\text { 3. Belum ada peraturan yang mengatur } \\
\text { seluruh kegiatan bisnis dalam kawasan } \\
\text { SKPT/No regulations that govern all } \\
\text { business activities in the SKPT area } \\
\text { 4. Kecemburuan sosial masyarakat yang } \\
\text { dapat menghambat aktifitas dalam } \\
\text { kawasan SKPT Biak/Social jealousy of the } \\
\text { community which can hamper activities in } \\
\text { the SKPT Biak area }\end{array}$ & $\begin{array}{l}\text { Melakukan pendekatan sosial kepada } \\
\text { masyarakat untuk memberikan } \\
\text { gambaran dampak positif pengelolaan } \\
\text { kawasan SKPT Biak dengan tetap } \\
\text { mempertahankan kearifan lokal / Take } \\
\text { a social approach to the community } \\
\text { to provide a positive impact on the } \\
\text { management of the SKPT Biak area } \\
\text { while maintaining local wisdom } \\
\text { (S2, S3, T2, T4) }\end{array}$ & $\begin{array}{l}\text { Harmonisasi peraturan dan } \\
\text { kebijakan dalam rangka } \\
\text { mendukung seluruh aktifitas } \\
\text { pelayanan dan bisnis dalam } \\
\text { kawasan SKPT Biak/Harmonization } \\
\text { of regulations and policies to } \\
\text { support all service and business } \\
\text { activities in the SKPT Biak area } \\
(\mathrm{W} 1, \mathrm{~T} 1, \mathrm{~T} 3)\end{array}$ \\
\hline
\end{tabular}

Peraturan dimaksud meliputi: UU Nomor 23 Tahun 2014, PP Nomor 75 Tahun 2015, Permendagri Nomor 19 Tahun 2019, dan Permen KP Nomor 46/ PERMEN-KP/2016. Sedangkan fungsi pelayanan dalam pengelolaan SKPT Biak diukur dengan mengetahui dampak positif dari pengelolaan SKPT yang diukur setiap tahun, yaitu meliputi dampak sosial, ekonomi, maupun lingkungan. Dengan menyusun strategi pada segmen arus pendapatan ini diharapkan adanya sumber pemasukan lain selain dari APBN serta untuk menghindari konflik karena wewenang penarikan tarif dan biaya sewa/ bagi hasil pengelolaan fasilitas usaha dalam kawasan SKPT Biak. Adapun faktor-faktor internal dan eksternal yang mempengaruhi segmen Arus Pendapatan dan hasil penyusunan alternatif strategi untuk segmen ini dapat dilihat pada Tabel 4. 
Tabel 4. Hasil Penyusunan Alternatif Strategi Segmen Arus Pendapatan. Table 4. Strategy Compilation Results for Revenue Streams Segments.

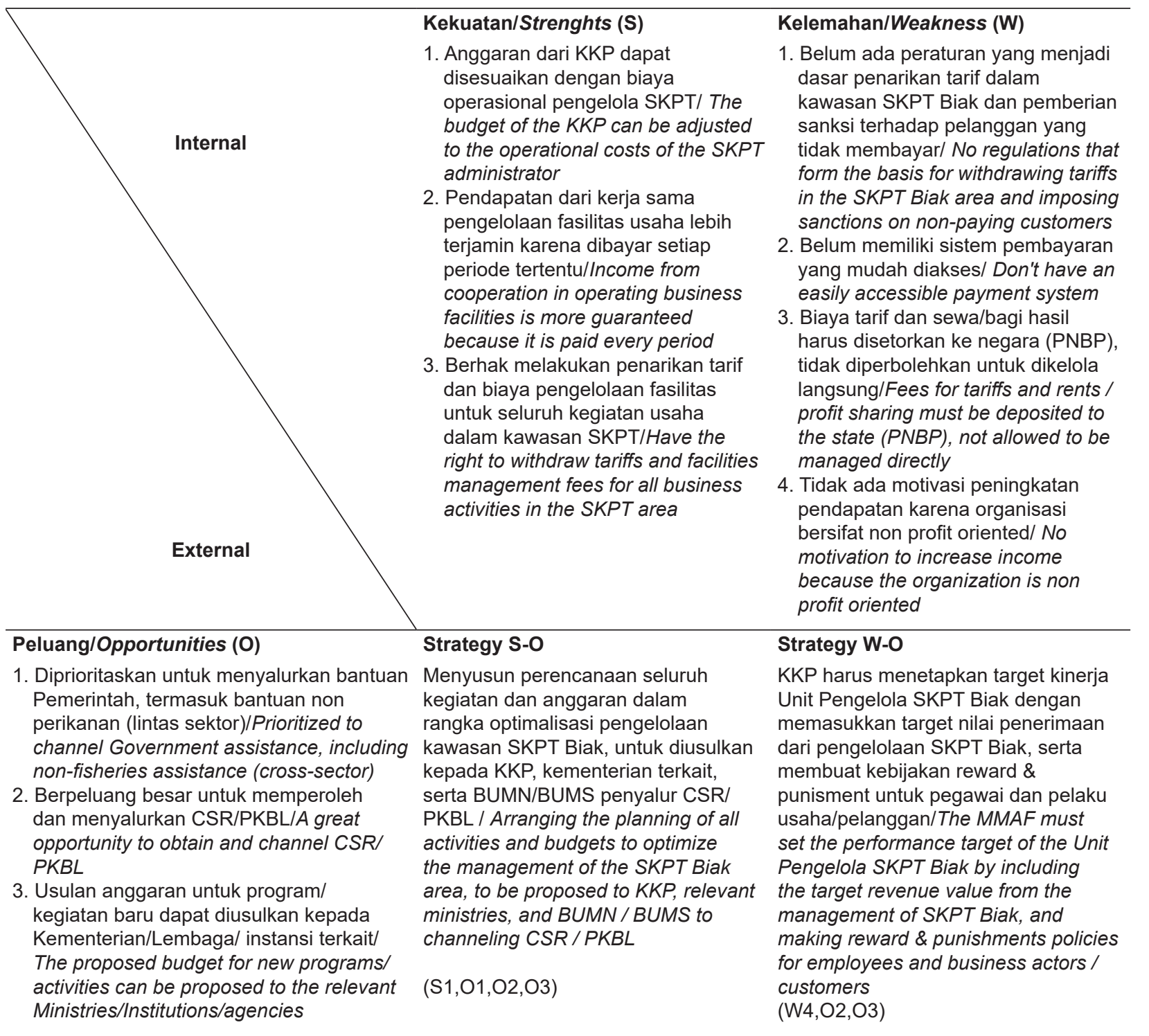

\section{Ancaman/Threats ( $\mathrm{T}$ )}

1. Adanya tunggakan dari pelanggan dan pengguna fasum/There are arrears from customers and users of public facilities

2. Keterlambatan pencairan anggaran dari kantor pusat (KKP)/Delay in disbursing the budget from the head office (MMAF)

3. Tuntutan pemasukan PAD dari Pemda/ Demands for revenue for the Regional Government

4. Adanya benturan kepentingan antara Pemeritah Pusat, Pemprov, dan Pemkab terkait penetapan tarif serta biaya dan wewenang pengelolaan fasilitas di kawasan SKPT Biak/Conflict of interest between the Central Government, Provincial Government, and Regency Government regarding the determination of tariffs and facilities management fees and authority in the Biak SKPT area

\section{Strategy S-T}

Membuat kebijakan penarikan tarif dan komisi (fee) terhadap penggunaan fasilitas usaha dan pendukung yang dapat digunakan sebagai biaya operasional dan pemeliharaan/Make a policy of withdrawing tariffs and commissions (fees) on the use of business and supporting facilities that can be used as operational and maintenance costs

$(\mathrm{S} 2, \mathrm{~S} 3, \mathrm{~T} 1, \mathrm{~T} 2)$

\section{Strategy W-T}

Penyusunan peraturan penerapan retribusi, sistem pembayaran, pengelolaan, dan sanksi, dengan melibatkan Pemeritah (Pusat dan Daerah), asosiasi usaha, dan instansi terkait lainnya/Making regulations for the application of levies, payment systems, management, and sanctions, by involving the Government, business associations, and other relevant agencies

(W1,W2,W3,T1,T3,T4) 


\section{PENETAPAN STRATEGI PRIORITAS}

Dari alternatif-alternatif strategi dari tiga segmen yang terpilih di atas, maka dilakukan pemilihan prioritas strategi dengan menggunakan AHP melalui aplikasi Expert Choice 11. Penetapan prioritas strategi ini bertujuan untuk memberikan rekomendasi kepada Pemerintah dan pemangku kepentingan dalam pengelolaan SKPT Biak sehingga implementasi pelaksanaan strategi dapat dimulai dari prioritas strategi yang terpilih. Hal tersebut tidak berarti bahwa alternatif strategi yang lain tidak dapat diterapkan, akan tetapi penerapan strategi ini perlu diprioritaskan dengan beberapa pertimbangan, antara lain: ketersediaan anggaran dan SDM, keterbatasan waktu, efisiensi kegiatan, serta landasan hukum. Selain itu, prioritas strategi ini juga harus memperhitungkan kapasitas sumber daya perikanan karena menurut Kjærsgaard (2010) pemanfaatan kapasitas sumber daya perikanan harus dilakukan secara optimal dengan memperhitungkan berbagai tujuan sehingga industri perikanan dapat berjalan secara berkelanjutan.

\section{A. Strategi Prioritas Segmen Proporsi Nilai}

Penyusunan alternatif strategi dengan analisis SWOT pada segmen proporsi nilai telah menghasilkan empat alternatif yang digambarkan pada Tabel 2, yaitu: Strategi S-O, Strategi W-O, Strategi S-T, dan Strategi W-T. Dengan menggunakan integrasi SWOT dan AHP maka hirarki pemilihan prioritas strategi segmen proporsi nilai dapat dilihat pada Gambar 3. Berdasarkan hasil pengolahan data terhadap faktor SWOT pada segmen proporsi nilai, maka disimpulkan bahwa faktor kekuatan (S) dinilai paling dominan dalam mempengaruhi pemilihan prioritas strategi pada segmen proporsi nilai. Dengan tingkat Inconsistency 0,00032, faktor kekuatan (S) memiliki bobot 0,398 . Pengambilan dan pengolahan data ini dinilai konsisten karena nilai Inconsistency masih jauh di bawah 0,25.

Selanjutnya analisis dilakukan untuk menentukan prioritas strategi pada segmen proporsi nilai, yaitu dari empat alternatif strategi yang telah disusun di atas. Dari keempat alternatif tersebut, strategi S-T yaitu "Mengoptimalkan semua sumber daya produksi (terutama SDM dan fasilitas dalam kawasan) untuk menciptakan nilai yang dapat meningkatkan loyalitas pelanggan dan mitra, serta untuk menarik pelanggan dan investor baru", dengan bobot 0,334 terpilih sebagai prioritas strategi untuk segmen proporsi nilai. Prioritas strategi tersebut diikuti dengan strategi S-O pada posisi kedua kemudian strategi $\mathrm{W}-\mathrm{O}$ dan strategi W-T pada posisi tiga atau empat karena kedua strategi tersebut memiliki bobot yang sama. Hasil pengambilan dan pengolahan data tersebut dinilai konsisten karena memiliki skala Inconsistency 0,02 . Hasil analisis dalam hirarki pemilihan prioritas strategi Segmen Proporsi Nilai dapat dilihat pada Gambar 3. Prioritas strategi yang terpilih tersebut memang relatif mudah diterapkan akan tetapi ketergantungan pelaku usaha perikanan terhadap subsidi maupun insentif/stimulan juga harus dihindari, seperti yang disampaikan MyongSop \&

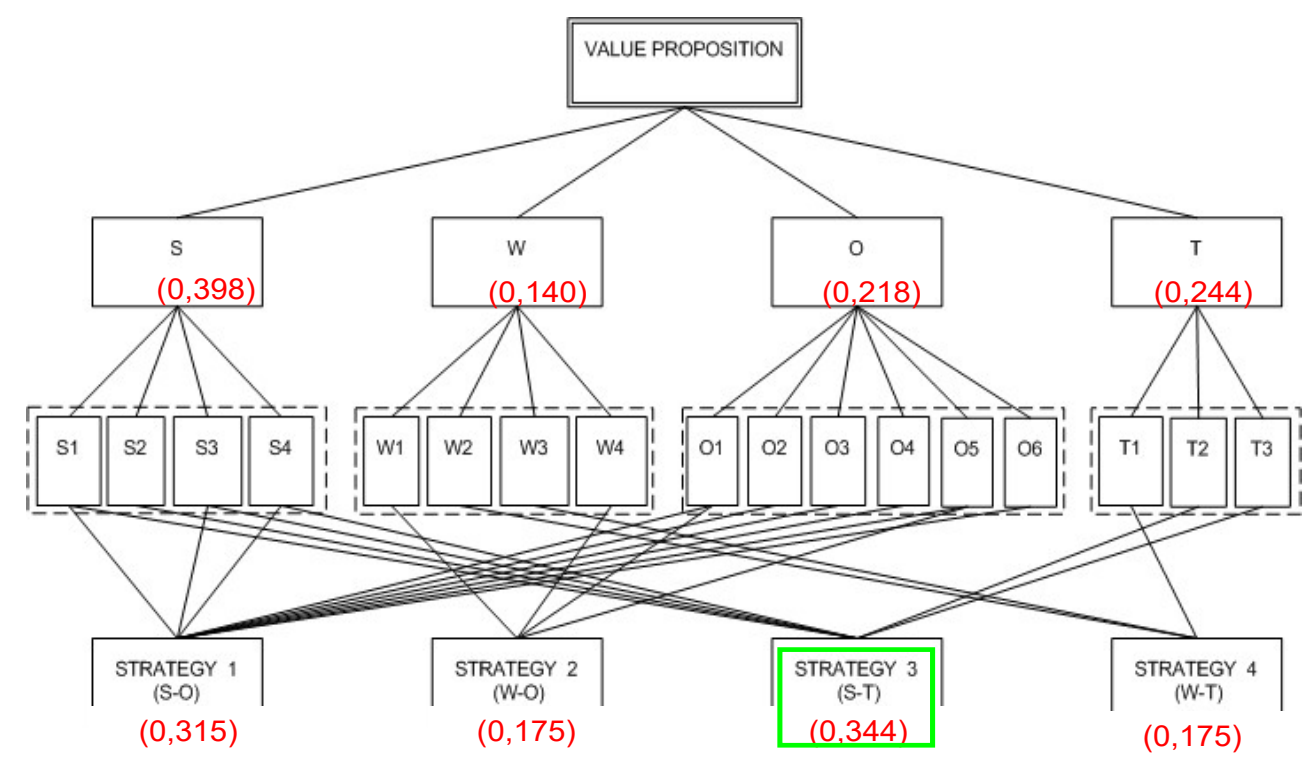

Gambar 3. Pemilihan Prioritas Strategi pada Segmen Proporsi Nilai.

Figure 3. Strategy Priorities Selection in the Value Proportion Segments. 
MoonBae (2002) bahwa tantangan besar industri perikanan di pasar internasional yaitu terkait pengurangan atau penghapusan subsidi perikanan. Hal lain yang perlu diantisipasi yaitu alokasi subsidi atau bantuan yang salah sasaran, seperti dalam penelitian Schuhbauer, Chuenpagdee, Cheung, Greer, \& Sumaila (2017) bahwa subsidi atau bantuan harus diarahkan ke pelaku usaha perikanan skala kecil untuk mengurangi ketidaksetaraan dengan usaha skala besar, meningkatkan kelayakan ekonomi, serta meningkatkan keberlanjutan perikanan.

\section{B. Strategi Prioritas Segmen Aktifitas Kunci}

Berdasarkan hasil penyusunan alternatif strategi pada segmen aktifitas kunci (Tabel 3), maka dilakukan pemilihan prioritas strategi dengan menggunakan integrasi SWOT dan AHP. Berdasarkan hasil pengolahan data terhadap faktor SWOT pada segmen aktifitas kunci, maka disimpulkan bahwa kelemahan (S) adalah faktor paling dominan dalam mempengaruhi pemilihan prioritas strategi pada segmen aktifitas kunci, dengan bobot 0,301 , diikuti oleh faktor kekuatan $(\mathrm{S})$, ancaman $(\mathrm{T})$, dan peluang $(\mathrm{O})$, rincian bobot dapat dilihat pada Gambar 4. Tingkat Inconsistency pada analisis ini yaitu 0,02 , sehingga dapat disimpulkan bahwa data ini konsisten.

Analisis untuk penentuan prioritas strategi pada segmen aktifitas kunci dilakukan dari empat alternatif strategi yang telah disusun di atas, dimana prioritas yang terpilih yaitu strategi
S-O "Melakukan promosi peluang investasi dan kerja sama, serta mengusulkan alokasi bantuan (termasuk lintas sektor) dalam rangka mengoptimalkan seluruh aktifitas dalam kawasan SKPT Biak". Prioritas strategi tersebut senada dengan penelitian Febriano, Hariyadi, \& Falatehan (2017), yang menyebutkan bahwa pengembangan investasi untuk kawasan industri penting dilakukan untuk mengembangkan suatu kawasan industri atau kawasan ekonomi secara tertintegrasi dan berkelanjutan. Strategi S-O memiliki bobot 0,277, kemudian diikuti dengan strategi $\mathrm{W}-\mathrm{T}$ pada posisi kedua, strategi S-T pada posisi ketiga, serta strategi W-O pada posisi keempat. Hasil pengambilan dan pengolahan data tersebut dinilai konsisten karena memiliki skala Inconsistency 0,03. Hasil analisis dalam hirarki pemilihan prioritas strategi Segmen Aktifitas Kunci dapat dilihat pada Gambar 4.

\section{Strategi Prioritas Segmen Arus Pendapatan}

Alternatif strategi hasil analisis SWOT pada segmen arus pendapatan, yaitu: Strategi S-O, Strategi W-O, Strategi S-T, dan Strategi W-T pada Tabel 4. Berdasarkan hasil pengolahan data terhadap faktor SWOT pada segmen arus pendapatan, maka disimpulkan bahwa faktor ancaman $(T)$ dinilai paling mempengaruhi pemilihan prioritas strategi pada segmen arus pendapatan. Dengan tingkat Inconsistency 0,02, faktor ancaman (T) memiliki bobot 0,299 diikuti oleh faktor kekuatan (S), peluang $(P)$, dan kelemahan $(W)$. Pengambilan dan pengolahan data ini dinilai konsisten karena nilai Inconsistency masih jauh di bawah 0,25.

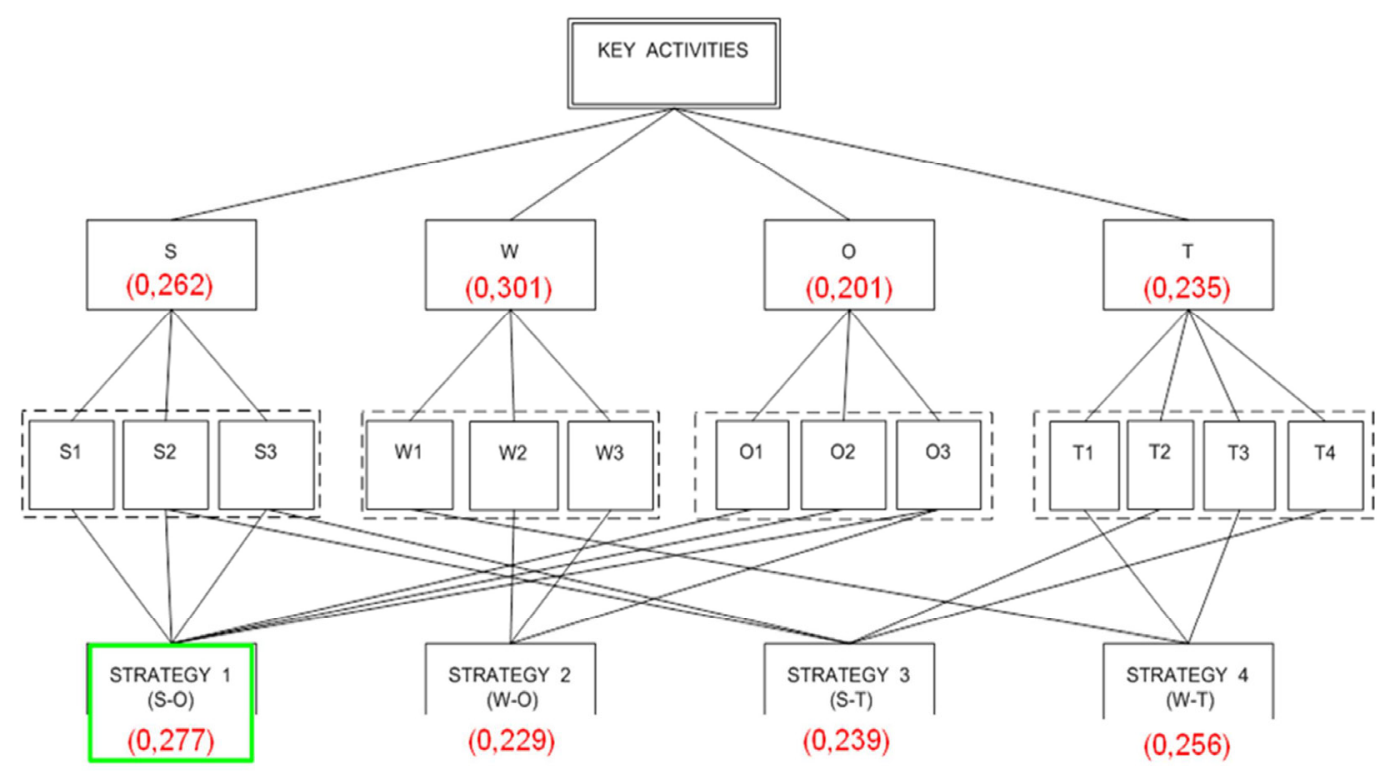

Gambar 4. Pemilihan Prioritas Strategi pada Segmen Arus Pendapatan. Figure 4. Strategy Priorities Selection in the Key Activities Segments. 
Selanjutnya analisis dilakukan untuk menentukan prioritas strategi pada segmen arus pendapatan, yaitu dari empat alternatif strategi yang telah disusun di atas. Dari keempat alternatif tersebut, strategi W-T yaitu " Penyusunan peraturan penerapan retribusi, sistem pembayaran, pengelolaan, dan sanksi, dengan melibatkan Pemeritah (Pusat dan Daerah), asosiasi usaha, dan instansi terkait lainnya", dengan bobot 0,283 terpilih sebagai prioritas strategi untuk segmen arus pendapatan. Prioritas strategi tersebut diikuti dengan strategi S-T pada posisi kedua, strategi S-O pada posisi ketiga, serta strategi $\mathrm{W}-\mathrm{O}$ pada posisi keempat. Hasil pengambilan dan pengolahan data tersebut dinilai konsisten karena memiliki skala Inconsistency 0,04. Penerapan strategi ini harus ditindaklanjuti dengan memberikan kepastian dan kecepatan layanan dalam pengelolaan kawasan (Suhardi, 2013). Selanjutnya hasil penyusunan peraturan dalam prioritas strategi juga harus disosialisasikan dengan baik karena menurut Silvani \& Amin (2016) faktor-faktor yang dapat menghambat penerapan retribusi/tarif yaitu kegiatan sosialisasi dan sumber daya manusia. Hasil analisis dalam hirarki pemilihan prioritas strategi Segmen Arus Pendapatan (Gambar 5).

Pada Gambar 4 tersebut dapat dilihat bahwa bobot strategi W-T berbeda sedikit dengan strategi S-T, yaitu "Menyusun perencanaan seluruh kegiatan dan anggaran dalam rangka optimalisasi pengelolaan kawasan SKPT Biak, untuk diusulkan kepada KKP, kementerian terkait, serta BUMN/ BUMS penyalur CSR/PKBL". Sehingga jika dilakukan analisis sensitifitas dengan menaikkan bobot kekuatan (S) menjadi 0,325 (sebelumnya 0,288 ), maka prioritas strategi akan berubah menjadi strategi ST dengan bobot sekitar 0,290, seperti pada Gambar 5. Oleh karena itu, diharapkan agar strategi W-T dan strategi S-T dapat dilakukan secara bersamaan pada segmen arus pendapatan sehingga mampu memberikan dampak yang lebih besar dari hasil pengelolaan SKPT Biak.

\section{PENUTUP}

Pengelolaan kawasan SKPT Biak dapat dilakukan secara optimal jika dilakukan secara terintegrasi dengan model dan strategi pengelolaan yang tepat. Model pengelolaan SKPT Biak harus mempertimbangkan tujuan SKPT (Missions) dan dampaknya (Impact \& Measurement) terhadap masyarakat Biak Numfor dan sekitarnya. Berdasarkan hasil penelitian, tiga segmen yang dinilai relatif lebih penting dan sangat mempengaruhi kesuksesan segmen lainnya yaitu : Proporsi Nilai (Value Proposition), Aktifitas Kunci (Key Activities), dan Arus Pendapatan (Revenue Streams). Identifikasi faktor internal dan eksternal dilakukan pada tiga segmen terpilih dan disusun dalam matrik SWOT yang digunakan sebagai acuan untuk menyusun 12 alternatif strategi, di mana masing-masing segmen diperoleh alternatif Strategi S-O, Strategi W-O, Strategi S-T, dan Strategi W-T. Prioritas strategi yang dihasilkan yaitu : (1) Mengoptimalkan semua sumber daya produksi (terutama SDM dan fasilitas dalam kawasan) untuk menciptakan nilai yang dapat meningkatkan loyalitas pelanggan dan mitra, serta untuk menarik pelanggan dan investor baru; (2) Melakukan

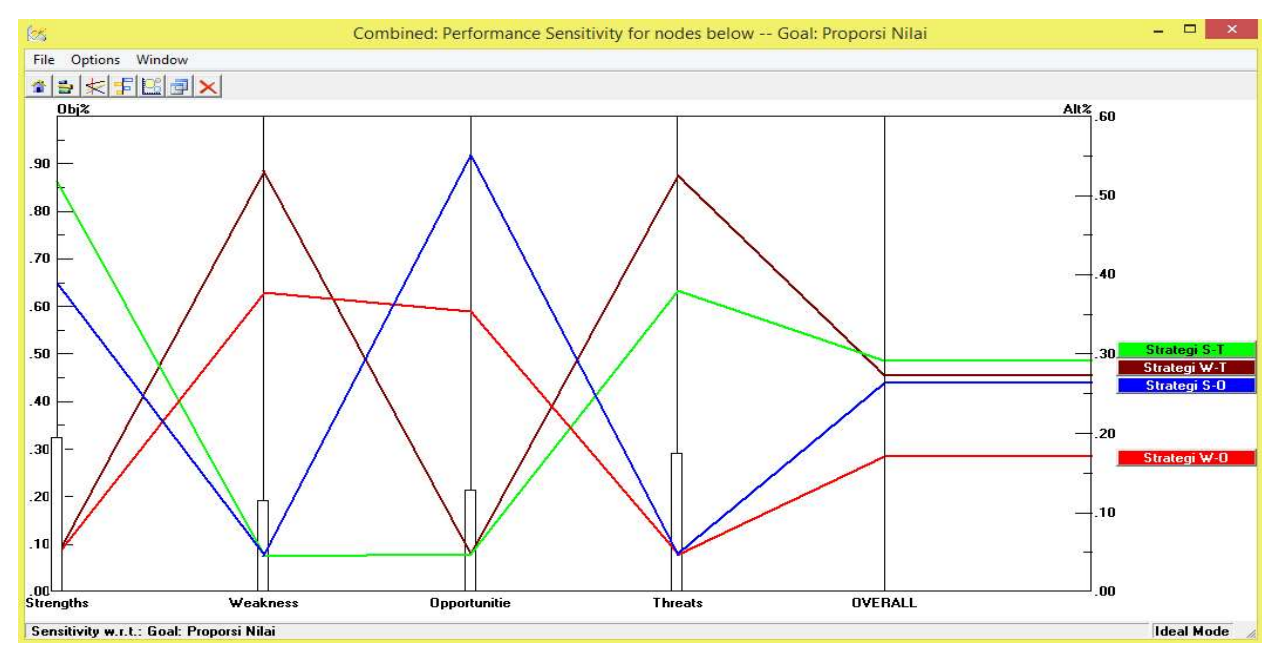

Gambar 5. Hasil Analisis Sensitifitas pada Strategi Segmen Arus Pendapatan. Figure 5. Sensitivity Analysis Results on the Revenue Streams Segment Strategy. 
promosi peluang investasi dan kerja sama, serta mengusulkan alokasi bantuan (termasuk lintas sektor) dalam rangka mengoptimalkan seluruh aktivitas dalam kawasan SKPT Biak; (3) Penyusunan peraturan penerapan retribusi, sistem pembayaran, pengelolaan, dan sanksi, dengan melibatkan Pemerintah (Pusat dan Daerah), asosiasi usaha, dan instansi terkait lainnya; serta (4) Menyusun perencanaan seluruh kegiatan dan anggaran dalam rangka optimalisasi pengelolaan kawasan SKPT Biak, untuk diusulkan kepada KKP, kementerian terkait, serta BUMN/BUMS penyalur CSR/PKBL. Berdasarkan hasil analisis yang telah dilakukan, implikasi kebijakan terhadap prioritas strategi yang dapat diterapkan dalam pengelolaan SKPT Biak antara lain : menginisiasi kerja sama dengan pemilik kapal besar untuk mengoptimalkan sumber daya ikan; revitalisasi dan optimalisasi pengelolaan fasilitas usaha dan pendukung; melakukan promosi peluang investasi dalam dan luar negeri; serta koordinasi dengan Pemerintah Kabupaten Biak Numfor dan Pemerintah Provindi Papua dalam rangka harmonisasi kebijakan dan penyusunan peraturan terkait pengelolaan SKPT Biak. Implikasi kebijakan tersebut harus dilakukan dengan melibatkan pihak-pihak terkait, antara lain : KKP dan Kementerian/Lembaga terkait; Pemerintah Provinsi Papua, Pemerintah Kabupaten Biak Numfor; asosiasi usaha perikanan; akademisi; dan instansi terkait lainnya.

\section{UCAPAN TERIMA KASIH}

Penelitian ini dapat terlaksana karena kerja sama yang baik dari berbagai pihak, sehingga kami ucapkan terima kasih terutama untuk Tim Pokja Pembangunan SKPT Biak dan jajaran dari Kementerian Kelautan dan Perikanan; Dinas Kelautan dan Perikanan Provinsi Papua; dan Dinas Perikanan Kabupaten Biak Numfor.

\section{DAFTAR PUSTAKA}

Adam, L., \& Surya, T.A. (2013). Kebijakan Pengembangan Perikanan Berkelanjutan di Indonesia. Jurnal Ekonomi Dan Kebijakan Publik, 4(2), 195-211. https://doi.org/10.22212/JEKP.V4I2.53.

Destiani, D. P. (2015). Analisis Strategi Model Bisnis Kanvas pada PT. Angkasa Pura II untuk Bandara Internasional Soekarno Hatta. Pusdiklat Perdagangan, 1, 1-21.

Dinas Perikanan Kabupaten Biak Numfor. (2018). Buku Laporan Tahunan Dinas Perikanan dan Kelautan Kabupaten Biak Numfor Tahun 2017. Biak : DP Kab. Biak Numfor.
Dinas Perikanan Kabupaten Biak Numfor. (2019). Buku Laporan Tahunan Dinas Perikanan dan Kelautan Kabupaten Biak Numfor Tahun 2018. Biak : DP Kab. Biak Numfor.

Febriano, M. R., Hariyadi, \& Falatehan, A. F. (2017). Strategi Pengelolaan Kawasan Ekonomi Khusus (KEK) Sei Mangke, Klaster Industri Hilir Kelapa Sawit Terintegrasi dan Berkelanjutan. Jurnal Agribisnis Sumatera Utara, 10(1), 22-35.

Johansen, U., Bull-Berg, H., Vik, L. H., Stokka, A. M., Richardsen, R., \& Winther, U. (2019). The Norwegian seafood industry - Importance for the national economy. Marine Policy, 103561. https:// doi.org/10.1016/j.marpol.2019.103561.

Kjærsgaard, J. (2010). Quest for appropriate overcapacity in the fisheries industry. Socio-Economic Planning Sciences, 44(3), 141-150. https://doi. org/10.1016/J.SEPS.2009.12.001.

[KKP] Kementerian Kelautan dan Perikanan. (2016). Masterplan dan Bisnisplan Pembangunan Sentra Kelautan dan Perikanan Terpadu (SKPT) Kabupaten Biak Numfor. Jakarta (ID): Kementerian Kelautan dan Perikanan.

Koeshendrajana, S., Zamroni, A., Asnawi, Wijaya, R. A., \& Rosyidah, L. (2018). Kajian Analisis Kebijakan Kelautan dan Perikanan: Upaya Percepatan Operasionalisasi Sentra Kelautan dan Perikanan Terpadu (SKPT) Kabupaten Biak Numfor, Provinsi Papua. Jakarta.

Kotler, P \& Keller, K.L. (2009). Manajemen Pemasaran. Jakarta (ID) : Erlangga.

Kurniasari, N., Rosidah, L., \& Erlina, M. D. (2019). Strategi Pengembangan Sektor Kelautan dan Perikanan di Kota Sabang. Jurnal Kebijakan Sosial Ekonomi Kelautan Dan Perikanan, 8(2), 125-135. https:// doi.org/10.15578/jksekp.v8i2.7321.

MyongSop, P., \& MoonBae, J. (2002). Korea's fisheries industry and government financial transfers. Marine Policy, 26(6), 429-435. https://doi. org/10.1016/S0308-597X(02)00023-4.

Osterwalder, A. \& Pigneur, Y. (2015). Business Model Generation. Jakarta (ID) : PT. Alex Media Komputindo.

Osuna, E.E. \& Aranda, A. (2007). Combining SWOT and AHP Techniques for Strategic Planning. Vina del Mar (Chile) : ISAHP.

Palilu, A. (2019). Sosialisasi Penanganan Konflik Sosial di Kelurahan Klawuyuk Kota Sorong. Journal of Dedication to Papua Community, 1(1), 22-31. https://doi.org/10.34124/266965.

Qastharin, A. R. (2016). A Business Model Canvas for Social Enterprises. Sains Humanika, 8(1-2), 627-637. https://doi.org/10.11113/sh.v8n1-2.825.

Rohy, J. B., Kadir, A. R., \& Alam, S. (2015). Blue Ocean Strategy Untuk Menetapkan New Bussiness 
Canvas Model Pada PT. Pelabuhan Indonesia IV (Persero). Magister Manajemen Universitas Hasanuddin Makassar.

Schuhbauer, A., Chuenpagdee, R., Cheung, W. W. L., Greer, K., \& Sumaila, U. R. (2017). How subsidies affect the economic viability of small-scale fisheries. Marine Policy, 82, 114-121. https://doi. org/10.1016/J.MARPOL.2017.05.013.

Silvani, \& Amin, R. M. (2016). Implementasi Perda Nomor 13 Tahun 2012 Tentang Retribusi Jasa Usaha Pelayanan Pelabuhan di Kabupaten Kepulauan Meranti. Jurnal Online Mahasiswa (JOM) Bidang IImu Sosial Dan Ilmu Politik, 3(2), 1-13. Retrieved from https://jom.unri.ac.id/index. php/JOMFSIP/article/view/11188.

Smith, S. L., Karasik, R., Stavrinaky, A., Uchida, H., \& Burden, M. (2019). Fishery Socioeconomic Outcomes Tool: A rapid assessment tool for evaluating socioeconomic performance of fisheries management. Marine Policy, 105, 20-29. https://doi.org/https://doi.org/10.1016/j. marpol.2019.03.009.

Suhardi, H. (2013). Perancangan Kanvas Model Bisnis PT. Sarana Bandar Nasional. Journal of Management and Business Review, 10(2), 120-139. Retrieved from http://jmbr.ppm-school. ac.id/index.php/jmbr/article/viewFile/64/51 .

\section{Peraturan Perundangan}

Undang-undang Republik Indonesia Nomor 23 Tahun 2014 tentang Pemerintah Daerah.

Peraturan Pemerintah Republik Indonesia Nomor 75 Tahun 2015 tentang Jenis dan Tarif Atas Jenis Penerimaan Negara Bukan Pajak yang berlaku pada Kementerian Kelautan dan Perikanan.

Peraturan Menteri Dalam Negeri Nomor 19 Tahun 2019 tentang Pedoman Pengelolaan Barang Milik Daerah.

Peraturan Menteri Kelautan dan Perikanan Republik Indonesia Nomor 46/PERMEN-KP/2016 tentang Tata Cara Pungutan Penerimaan Negara Bukan Pajak di Lingkungan Kementerian Kelautan dan Perikanan di Luar Pungutan Perikanan.

Surat Keputusan Menteri Nomor 51/KEPMEN-KP/2016 tentang Penetapan Lokasi Pembangunan Sentra Kelautan dan Perikanan Terpadu di Pulau-Pulau Kecil dan Kawasan Perbatasan. 